\title{
Probability-Based Seismic Performance Evaluation for Buildings
}

\section{Jeng-Hsiang Lin}

Department of Architecture, Hwa Hsia University of Technology, Taiwan

Email: hsiang@cc.hwh.edu.tw

How to cite this paper: Lin, J.-H. (2016) Probability-Based Seismic Performance Evaluation for Buildings. World Journal of Engineering and Technology, 4, 8-14. http://dx.doi.org/10.4236/wjet.2016.43C002

Received: May 2, 2016

Accepted: September 19, 2016

Published: September 22, 2016

\begin{abstract}
Recent developments in earthquake engineering indicate that probabilistic seismic risk analysis (PSRA) is becoming increasingly useful for the evaluation of structural performance in accordance with building codes. In recent years, the field of seismic resistance design has been undergoing a critical shift in focus from strength to performance. However, current earthquake resistant design procedures do not relate building performance to probability. A lack of sufficient empirical data has highlighted gaps in this research. This study integrated results from the analysis of structural fragility and seismic hazard in Taiwan to perform PSRA to examine the effectiveness of building code in mitigating the risks associated with earthquakes. Factors taken into account included the effect of construction materials, building height, and building age. The results of this study show that the probability of exceeding damage associated with the CP level in buildings of light steel, pre-cast concrete, and masonry, exceeds $2 \%$. These buildings fail to meet the performance objectives outlined in FEMA-273.
\end{abstract}

\section{Keywords}

Seismic Performance, Building, Earthquake Resistant Design, Performance Levels

\section{Introduction}

Structural failures observed after the 1994 Northridge, 1995 Kobe, and 1999 Chi-Chi earthquakes have exposed the vulnerability of designs and highlighted the need for new concepts and methodologies in the evaluation of building performance. Strength and performance are both considered important elements in modern building codes [1]-[3]. The development of these codes from the perspective that a certain amount of structural failure or damage can be tolerated, provided it occurs gradually and in a controlled manner. 
Recent developments in earthquake engineering indicate that probabilistic seismic risk analysis (PSRA) is becoming increasingly useful for the evaluation of structural performance in accordance with building codes. PSRA makes it possible to quantify the probability of structural failure during earthquakes [4]-[8]. However, current design procedures do not relate building performance to probability. Oversimplification in measurement algorithms and a lack of sufficient empirical data has created a gap in research into seismic design. The question of what constitutes acceptable risk remains context-specific.

This study focuses on the application of probability to the evaluation of building performance in terms of earthquake resistance. To examine the effectiveness of Taiwan's current building codes in earthquake risk mitigation and the development of seismic resistance designs, this study investigated and compared the exceedance probability of various performance levels for 15 classified buildings over a 50-year period. The effects of construction materials, building height, and building age on exceedance probability of various performance levels were detected and discussed. Our results contribute substantially to the field of earthquake engineering by providing a reference for code writers, researchers, and structural engineers.

\section{Performance Levels}

Many studies [9]-[13] have concluded that the interstory drift is the critical parameter that is best correlated with damage in buildings. FEMA-273 [14] relates interstory drifts to the following performance levels: Operational (O), Immediate Occupancy (IO), Life Safety (LS) and Collapse Prevention (CP). Definitions of these performance levels are also presented in this document. Higher performance corresponds to less economic loss. Performance objectives assign minimum performance levels for each measured level of ground motion intensity. This implies that if specified ground motion corresponding to a specified mean return period (MRP) of time occurs beneath a building designed according to FEMA-273 standards, then damage will be limited to that outlined by the performance objective.

In performance-based seismic design, a failure event is said to have occurred when the structure fails to satisfy the requirements of a prescribed performance level. Damage limits are a common factor considered in PSRA. As suggested by FEMA (1997) and adopted in the program of the Taiwan Earthquake Loss Estimation System (TELES) [15], four limit states (LS), including slight, moderate, extensive and complete and five damage states (DS) including none, slight, moderate, extensive and complete were considered in this study.

A performance objective consists of a structural performance level and the estimated probability that this performance level will be exceeded. For example, buildings designed in accordance with FEMA-350 [16] are expected to provide less than a $2 \%$ chance of suffering damage exceeding the $\mathrm{CP}$ level over a period of 50 years. Commentary to the NEHRP Recommended Provisions [17] recommends that buildings have less than a $50 \%$ chance over 50 years (50\%/50years) of suffering damage exceeding the IO 
level. In other words, buildings are expected to have at least a $50 \%$ chance of satisfying requirements of IO over a period of 50 years.

\section{Probabilistic Seismic Risk Analysis}

Probabilistic seismic risk analysis (PSRA) requires the identification of seismic hazards and analysis of structural fragility as well as calculations regarding the probability that limit states and/or damage states will be exceeded. Lin [8] presented a probabilistic framework for evaluating the probability. The framework was adopted in this study.

A seismic hazard curve displays the probability of ground motion reaching or exceeding a given intensity at a specific site within a specified period of time (e.g. one year). The average annual risk $\gamma_{1}$ can be translated into the probability $\gamma_{t}$ that the intensity of ground motion will be exceeded in the next $t$ years. Equation (1) shows the relationship between $\gamma_{t}$ and $\gamma_{1}$.

$$
\gamma_{t}=1-\left(1-\gamma_{1}\right)^{t}
$$

Fragility assessment describes the performance of the system as a whole with respect to a specified limit state of performance, measured in terms of deformation. Fragility curves are useful tools for predicting the extent of damage likely to occur in structures. A probabilistic framework is used to model sources of uncertainty capable of affecting building performance. Each point on the fragility curve represents the probability that the response of the structure to ground shaking of a given intensity is greater than the response associated with a specified limit state.

Previous researches [13] [18] [19] had modeled fragility curves using a lognormal cumulative distribution function, defined by the median value (50th percentile fragility) $m$ and a logarithmic standard deviation $\beta$ of the intensity of PGA, and described by

$$
F(a)=\Phi[\ln (a / m) / \beta]
$$

where $\Phi[$.$] is the standard normal probability integral and a=$ PGA.

\section{Numerical Examples}

This study sampled buildings located in the city of Taichung, a major metropolitan area in central Taiwan. The buildings were classified into 15 types according to the materials used in construction (wood (W), steel (S), light steel (S2), reinforced concrete (C), precast concrete (PC), reinforced masonry (RM), un-reinforced masonry (URM), or steel reinforced concrete (SRC)) and building height (low-rise (L: 1 - 3 stories), mid-rise (M: 4 - 7 stories), or high-rise (H: $8+$ stories)). These are the same classifications adopted by the TELES. For each building type in the TELES, there are three design levels: high, moderate and low, based on modern seismic code design requirements for buildings located in high, moderate, and low seismic zones, respectively, to be considered in response to the effects of seismic zone, construction years and the developments of building code in Taiwan. According to current building codes in Taiwan, Taichung city is considered an area of high seismic activity. 
To facilitate our assessment of vulnerability, this study adopted the parameters values generated by Liao et al. [19] for the fragility curves of buildings classified according to TELES. For example, the median values used to construct the fragility curves of a high-code, mid-rise reinforced concrete building (Label CM) for the limit states of slight, moderate, extensive, and complete are $0.33,0.59,0.71$, and 0.8 g, respectively. The logarithmic standard deviations of the intensity of ground shaking for this case are equal to $0.5,0.45,0.4$, and 0.4 for the limit states of slight, moderate, extensive, and complete, respectively.

Table 1 shows the exceedance probabilities for all of the classified buildings are on the order of $10^{-2}$ (ranging from 0.006 to 0.044 ) for the CP level, on the order of $10^{-2}$ (ranging from 0.011 to 0.069 ) for the LS level, and on the order of $10^{-1}$ (ranging from 0.027 to 0.155 ) for the IO level. Significant variations were observed among the various building categories. Compared with reinforced concrete, steel, steel reinforced concrete, and wood, buildings constructed of light steel, pre-cast concrete, reinforced masonry, and un-reinforced masonry were at higher risk of collapse due to seismic activity. As previously mentioned, according to FEMA-350, buildings are expected to have a less than $2 \%$ chance of suffering damage exceeding the CP level. In buildings of light steel, pre-cast concrete, reinforced masonry, and un-reinforced masonry, the probability of exceeding damage associated with the $\mathrm{CP}$ level exceeded $2 \%$. This means that the $\mathrm{CP}$ performance level is not realized in buildings of this type. The 50\%/50 years exceedance probability limit set for the IO level by the NEHRP was met for all of the buildings in the sample, as shown in Table 1.

The moderate design level applies to buildings constructed during the period 1968 2000. Buildings constructed prior to 1968 do not conform to modern building standards, and are therefore assigned a low design level. To further detect the effect of building age, this study investigated the relationships between building age and the exceedance probabilities of various performance levels. Figure 1 shows the relationships between building age and exceedance probability of various performance levels for the mid-rise reinforced concrete buildings for different construction years. As shown in Figure 1, the exceedance probability increases with building age and decreases with the developments of seismic design code. For a specified building age (e.g. 50 years), the exceedance probability increases with performance. Similar results were found in building constructed of different materials.

Table 1. Effects of construction materials and building height on exceedance probability of various performance levels.

\begin{tabular}{|c|c|c|c|c|c|c|c|c|c|c|c|c|c|c|c|}
\hline \multirow{2}{*}{$\begin{array}{l}\text { Performance } \\
\text { level }\end{array}$} & \multicolumn{15}{|c|}{ Building classification } \\
\hline & CL & $\mathrm{CM}$ & $\mathrm{CH}$ & SRCL & SRCM & $\mathrm{SRCH}$ & SL & SM & $\mathrm{SH}$ & S2 & PCL & RML & $\mathrm{RMM}$ & URML & $\mathrm{W}$ \\
\hline IO & 0.052 & 0.038 & 0.052 & 0.027 & 0.034 & 0.052 & 0.052 & 0.052 & 0.044 & 0.106 & 0.074 & 0.113 & 0.113 & 0.155 & 0.038 \\
\hline LS & 0.022 & 0.016 & 0.014 & 0.011 & 0.014 & 0.014 & 0.014 & 0.016 & 0.013 & 0.064 & 0.044 & 0.047 & 0.047 & 0.069 & 0.016 \\
\hline
\end{tabular}



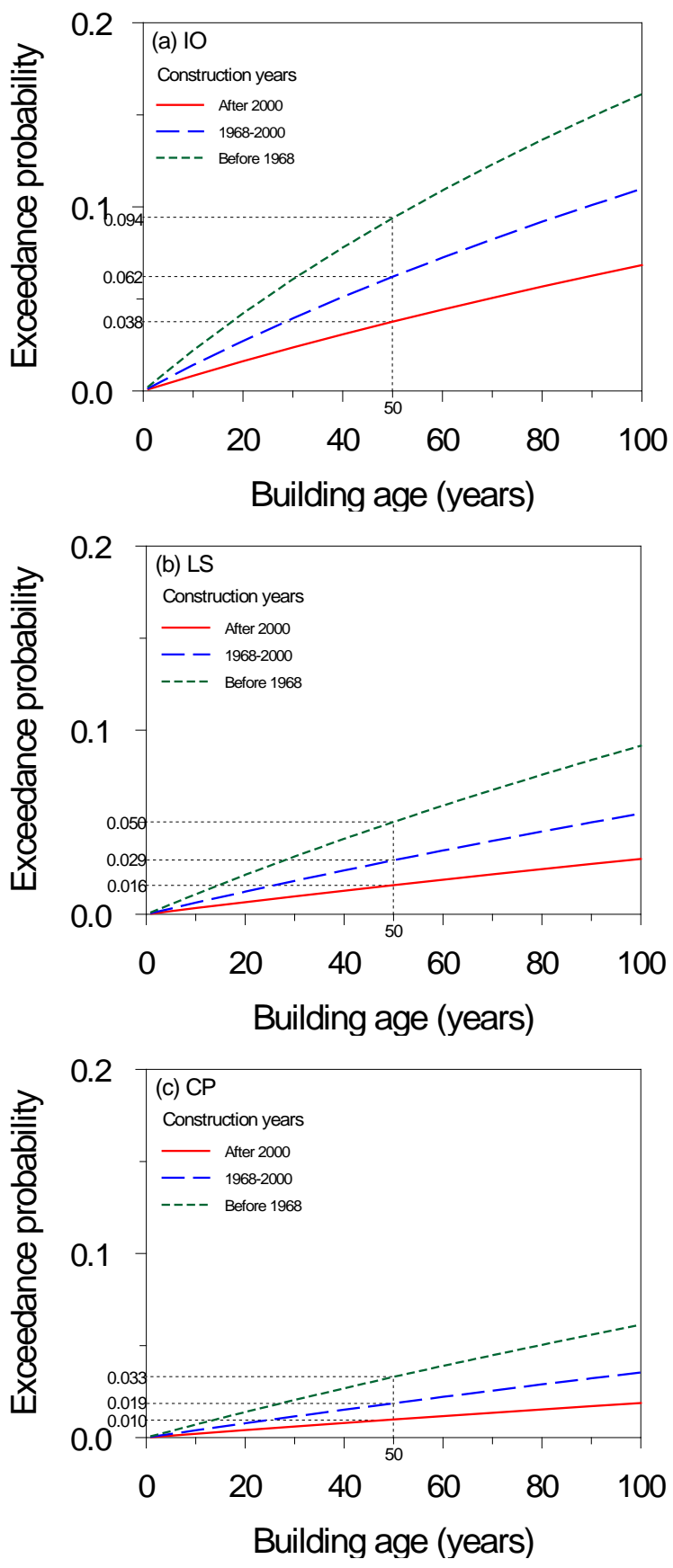

Figure 1. Effect of building age on exceedance probability of performance levels: (a) IO; (b) LS; (c) $\mathrm{CP}$ for the mid-rise reinforced concrete buildings for various construction years.

\section{Summary}

By applying the concept of probability to the evaluation of earthquake-resistant design, this study performed PSRA to examine the effectiveness of Taiwan building code in mitigating the risks associated with earthquakes. The influence of construction material, building height, and building age on the exceedance probability of various performance levels (IO, LS, and CP) was investigated. 
The observations from this study demonstrate the importance of these issues in the PSRA of buildings. The results revealed significant differences among the building categories with regard to vulnerabilities in the event of earthquakes. In other words, the design procedure used in the current Taiwan building code leads to non-uniform level of risk for different buildings. According to FEMA-350, buildings are expected to have a less than $2 \%$ chance of suffering damage exceeding the CP level. In buildings of light steel, pre-cast concrete, and masonry, the probability of exceeding damage associated with the $\mathrm{CP}$ level exceeds $2 \%$. These results provide a valuable reference for the further development of building codes in Taiwan as well as future study into performancebased design procedures.

\section{Acknowledgements}

This work was supported by Hwa Hsia University of Technology under Grant $\mathrm{HWH}$ 105-H-008.

\section{References}

[1] ICC (2012) International Building Code. International Code Council, Whittier, CA.

[2] ICBO (1997) Uniform Building Code. International Conference of Building Officials, Whittier, CA.

[3] FEMA (2000) Prestandard and Commentary for the Seismic Rehabilitation of Buildings. Report No. 356, Federal Emergency Management Agency, Washington DC.

[4] Ellingwood, B. (2001) Earthquake Risk Assessment of Building Structures. Reliability Engineering and System Safety, 74, 251-262. http://dx.doi.org/10.1016/S0951-8320(01)00105-3

[5] Fischer, T., Alvarez, M., De la Llera, J.C. and Riddell, R. (2002) An Integrated Model for Earthquake Risk Assessment of Buildings. Engineering Structures, 24, 979-998.

http://dx.doi.org/10.1016/S0141-0296(02)00018-4

[6] Goulet, C.A., Haselton, C.B., Mitrani-Reiser, J., Beck, J.L., Deierlein, G.G. and Stewart, J.P. (2007) Evaluation of the Seismic Performance of a Code-Conforming Reinforced-Concrete Frame Building-From Seismic Hazard to Collapse Safety and Economic Losses. Earthquake Engineering and Structural Dynamics, 36, 1973-1997. http://dx.doi.org/10.1002/eqe.694

[7] Ellingwood, B. and Kinali, K. (2009) Quantifying and Communicating Uncertainty in Seismic Risk Assessment. Structural Safety, 31, 179-187.

http://dx.doi.org/10.1016/j.strusafe.2008.06.001

[8] Lin, J.H. (2012) Exceedance Probability of Extensive Damage Limit for General Buildings in Taiwan. Disaster Prevention and Management, 12, 451-463. http://dx.doi.org/10.1108/09653561211234543

[9] Sozen, M.A. (1983) Lateral Drift of Reinforced Concrete Structures Subjected to Strong Ground Motion. Bull. New Zealand Natl. Soc. Earthquake Engineering, 16, 107-122.

[10] Moehle, J.P. (1994) Seismic Drift and Its Role in Design. Proc., 5th US-Japan Workshop on the Improvement of Building Structural Design and Construction Practices, San Diego, 65-78.

[11] Gülkan, P. and Sozen, M.A. (1999) Procedure for Determining Seismic Vulnerability of Building Structures. ACI Structural Journal, 96, 336-342. 
[12] Akkar, S., Yazgan, U. and Gülkan, P. (2005) Drift Estimates in Frame Buildings Subjected to Near-fault Ground Motions. Journal of Structural Engineering, 131, 1014-1024. http://dx.doi.org/10.1061/(ASCE)0733-9445(2005)131:7(1014)

[13] Lin, J.H. (2008) Seismic Fragility Analysis of Frame Structures. International Journal of Structural Stability and Dynamics, 8, 451-463. http://dx.doi.org/10.1142/S0219455408002740

[14] FEMA (1997) NEHRP Guidelines for the Seismic Rehabilitation of Buildings. Report No. 273, Federal Emergency Management Agency, Washington DC.

[15] Yeh, C.H., Loh, C.H. and Tsai, K.C. (2006) Overview of Taiwan Earthquake Loss Estimation System. Natural Hazards, 37, 23-37. http://dx.doi.org/10.1007/s11069-005-4654-Z

[16] FEMA (2000) Recommended Seismic Design Criteria for New Steel Moment Frame Buildings. Report No. 350, Federal Emergency Management Agency, Washington DC.

[17] FEMA (1998) NEHRP Recommended Provisions for Seismic Regulations for New Buildings and Other Structures, Part 2: Commentary. Report No. 303, Federal Emergency Management Agency, Washington DC.

[18] Shinozuka, M., Feng, M.Q., Lee, J. and Naganuma, T. (2000) Statistical Analysis of Fragility Curves. Journal of Engineering Mechanics, 126, 1224-1231. http://dx.doi.org/10.1061/(ASCE)0733-9399(2000)126:12(1224)

[19] Liao, W.I., Loh, C.H. and Tsai, K.C. (2006) Study on the Fragility of Buildings Structures in Taiwan. Natural Hazards, 37, 55-69. http://dx.doi.org/10.1007/s11069-005-4656-x

\section{Submit or recommend next manuscript to SCIRP and we will provide best service for you:}

Accepting pre-submission inquiries through Email, Facebook, LinkedIn, Twitter, etc.

A wide selection of journals (inclusive of 9 subjects, more than 200 journals)

Providing 24-hour high-quality service

User-friendly online submission system

Fair and swift peer-review system

Efficient typesetting and proofreading procedure

Display of the result of downloads and visits, as well as the number of cited articles

Maximum dissemination of your research work

Submit your manuscript at: http://papersubmission.scirp.org/ 